\title{
A Critical Reading of Walter Benjamin's The work of art in the age of mechanical reproduction
}

\author{
Paulo Domenech Oneto*
}

\section{Resumo}

Minha intenção é apresentar uma resenha crítica do mais festejado ensaio de Walter Benjamin, intitulado "A obra de arte na era de sua reprodutibilidade técnica". Várias dificuldades numa primeira leitura desse texto, especialmente devido a um contraste sensível entre sua brevidade e o grande número de questões por ele levantadas. As razões para isso residem nas próprias circunstâncias em que o ensaio foi escrito, mas se devem igualmente ao estilo epigramático adotado pelo filósofo. Isto por si só já constituiria um ótimo tópico de análise. Pretendo, porém, enfatizar outros aspectos: 1) o contexto em que o texto foi produzido, a fim de mostrar que se trata de uma espécie de manifesto; 2) o desenvolvimento do conceito-chave de "aura", que já havia sido mencionado num texto anterior ("Sobre alguns motivos de Baudelaire"); 3) a questão da "politização da arte", conforme aparece no epílogo do ensaio.

Palavras-chave - arte, política, estetização, aura, vontade de arte

\section{Abstract}

My intent is to offer a critical report of Walter Benjamin's most celebrated essay, "The Work of Art in the Age of Mechanical Reproduction". Many difficulties arise from a first reading of the text, notably because of a striking contrast between its shortness and the large number of issues raised. The reasons for that lie on the circumstances in which the essay was written, but may also be related to the philosopher's epigrammatic style. This latter topic could alone be a theme for a paper and I cannot provide a fair account of the problem here. Instead, I will emphasize three aspects of Benjamin's essay: 1) the context in which it was produced, in an attempt to show that it can be seen as a kind of

\footnotetext{
${ }^{1}$ This paper was originally written in the United States six years ago. It has remained unpublished until the present date for several reasons, mostly because of my sudden return to Brazil the following year (2003). I have now decided to submit it to the recent created Cadernos Benjamin in order to establish a communication with Professor Tereza de Castro Callado (a specialist in Benjamin's work) and with a group of graduate students of UECE (Universidade Estadual do Ceará) who have shown great interest in the philosopher's thought. I found quite promising to "discover" a generation of philosophy readers who think beyond the German mainstream (the tradition of "philosophy workers", criticized by Nietzsche) which unfortunately seems to prevail in Ceará. In the $20^{\text {th }}$ century panorama, Benjamin's thought represents one of the most consistent enterprises of resistance to the trends of logicism and moral foundationalism. Both assail the contemporary attempts to produce philosophy in a new key. If the dangers of an "aestheticization of politics" are not at stake in our days, one cannot say the same of the reduction of philosophy to logical systems (modes of representation) - theme of Benjamin's The Origin of German Baroque Drama. In this sense, it would be more useful to write an essay on this latter work. Yet, I believe that the simple mention to Benjamin, together with a consideration of his commitment to art, may suffice to keep the spark of creation in the core of philosophy, against the Kantian-Hegelian and analytic bureaucratic tendencies. I hope to present a Portuguese version of this paper soon, so that the intended dialogue may become easier in a near future.

* PhD for the Université de Nice (Philosophy, 2001). Professor in the Graduate Program of the UGF-RJ Universidade Gama Filho no Rio de Janeiro. Graduate student in the Comparative Literature Department at the University of Geórgia - USA, 1994-1995 an 2002-2003.
} 
manifesto; 2) the development of the key-concept of "aura", already mentioned in an earlier text ("On Some Motifs of Baudelaire"); 3) the question of "politicization of art", as it appears in the epilogue.

Key-words - art, politics, aura, aestheticization, will to art.

\section{A Critical Reading of Walter Benjamin's The work of art in the age of mechanical reproduction}

\section{Introduction}

Walter Benjamin's short and polemic essay, titled "The Work of Art in the Age of Mechanical Reproduction", first appeared in France 1936. The text is divided into 19 sections (15 sections and an epilogue in the original manuscript used in Hannah Arendt's edition of 1955, titled Illuminations and translated into English in 1968). Its central thesis is somehow summarized in section II, immediately after the introduction of the key-concept of "aura":

One might generalize [Benjamin's argument about the withering of the "aura"] by saying: the technique of reproduction detaches the reproduced object from the domain of tradition. By making many reproductions it substitutes a plurality of copies for a unique existence. And in permitting the reproduction to meet the beholder or listener in his own particular situation, it reactivates the object reproduced. These two processes lead to a tremendous shattering of tradition, which is the obverse of the contemporary crisis and renewal of mankind. Both processes are intimately connected with the contemporary mass movements. Their most powerful agent is film. Its social significance, particularly in its most positive form, is inconceivable without its destructive, cathartic aspect, that is, the liquidation of the traditional value of the cultural heritage. ("The Work of Art in the Age of Mechanical Reproduction", 221)

Benjamin does not fail to point out that works of art have always been reproducible throughout history. For instance, he mentions the procedures of founding and stamping in ancient Greece, the medieval additions to the development of woodcut graphic art (engraving and etching), the appearance of lithography in the nineteenth century. His argument, however, is that mechanical reproduction, which is a result of the advanced stage of capitalism he is living in, represents something new ("The Work of Art", 218-219). It is precisely the novelty of these arts of reproduction such as photography and film that deserves to be analyzed in detail. After all, according to the philosopher, such changes entail a new concept of art - a concept that makes art absolutely inseparable from politics.

In fact, Benjamin's own political motivations - in the strongest sense of the word - for writing the essay are set forth from the very beginning. The connection between the two processes mentioned above (copying and distributing the works of art) and the mass movements delineate the context. It is a political-historical context. As we read in the "Preface", theses about the art of the proletariat or the art of a classless society - especially those on the developmental tendencies of art under certain conditions - become important weapons (sic) against the use of traditional aesthetic concepts (creativity, genius etc.) by Fascism ("The Work of Art", 218). Even though this political terminology recedes in the following sections until the "Epilogue", it is clear that the essay's main goal is precisely the one Benjamin assigns to Communism: to block the resilient tendency for an aestheticization of politics initiated or reinforced by Giacomo Marinetti's Futurist manifesto.

Thus, it seems that "The Work of Art in the Age of Mechanical Reproduction" must be seen more as a sort of pamphlet or manifesto than anything else. And it is probably the urgency intrinsic to manifestos that makes several passages of the essay sound too 
straightforward or sectary. However, if one acknowledges that a second framing is necessary to the text - not only a view of its historical context (the essay as part of a political agenda), but also in relation to other of Benjamin's writings -, the enchaining of arguments can appear in a new light.

For instance, a previous conference given two years earlier ("The Author as Producer", 1934) clearly shows two important aspects of Benjamin's analysis of art in his new age. First: in spite of his emphasis on the role played by mechanical reproduction, Benjamin is still far from denying a degree of autonomy for the artist in the process of artistic creation, as some readers claim. Second: in spite of his demand for a revolutionary art, the philosopher always insists on the necessity of developing a literary technique capable of awaken a critical attitude in the audience. That was the case of Bertolt Brecht's Epic Theater, for example:

[A] work of literature can be politically correct only if it is also correct in the literary sense. (...) By mentioning technique I have named the concept which makes literary products accessible to immediate social, and therefore materialist, analysis. At the same time, the concept of technique represents the dialectical starting-point from which the sterile dichotomy of form and content can be surmounted. ("The Author as Producer", 93-94)

In other words, in literature (art in general) there is neither a "revolutionary content" separated from form to be conveyed, nor a technical medium, independent from the artistproducer who would be more or less capable of conveying it. Now, it suffices to transpose the argument to the scenario of "The Work of art in the Age of Mechanical Reproduction" to understand that Benjamin never celebrates a dismissal of creativity for political reasons, in a socialist realism manner. Accordingly, he never suggests that new media such as photography and film are revolutionary in themselves.

A close reading of another of his previous texts ("A Small History of Photography", 1931) may also be quite useful to make the reader avoid a second prejudice against Benjamin, namely the one that attributes to him a sort of naïve optimism about the new arts of reproduction ${ }^{2}$. Throughout the text, instead of an absolute positive evaluation of photography, what we find is something much more subtle: a kind of relative approach, as when he mentions the difference between the surrealist photographer Eugène Atget and other artists:

He was the first to disinfect the stifling atmosphere generated by conventional photography in the age of decline. He cleanses this atmosphere, indeed he dispels it altogether: he initiates the emancipation of object from aura which is the most signal achievement of the latest school of photography. (ROCHLITZ, quoted, 152).

Once again, one must argue from the passage above that Benjamin's idea is not that photography is in itself more revolutionary than other arts, but rather that its novelty (and film's novelty too) entails a "decline of the aura" and discloses new possibilities for art. On the other hand, it was perhaps hasty to draw conclusions about the use of new artistic media as he did. It is true that "even if we except commercial film, film itself has hardly evolved in the direction of politicization announced by Benjamin" (ROCHLITZ, 149). In fact, one can

\footnotetext{
${ }^{2}$ As a matter of fact, both prejudices - the one about a dismissal of creativity in the realm of a revolutionary art, and the second, about Benjamin's "optimism", seem to be present in Theodor Adorno's letter to Benjamin, written soon after his reception of the essay: "what I postulate is more dialectics. On the one hand, dialectical penetration of the 'autonomous' work of art (...) transcended by its own technology into a planned work; on the other, an even stronger dialecticization of utilitarian art in its negativity" (in TAYLOR, 124). As for Benjamin's optimism, it seems that he may be seen as optimistic rather about the artist and the audience, not about the media themselves.
} 
even see the history of cinema as going exactly in the opposite direction - "commodification" took over artistic creation, in an unfolding much closer to Adorno's pessimistic views about the destiny of art in our capitalist mass society. Yet, Benjamin's ideas about politics in film refer to those that explicitly claim aesthetic purposes. His thesis refers to art, not to mere entertainment.

At any rate, the questions we need to ask ourselves concern the scope of Benjamin's concept of "aura" because it is this aura of the work of art that tends to disappear with the advent of the arts of reproduction (photography and film).

What does the term mean exactly? How can artwork reproduction entail a "decay of this aura"? Why does such a decline represent a positive event in terms of politicization? What does Benjamin mean by politics in his essay?

\section{The Concept of "Aura"}

The first mention of the theme occurs in Benjamin's Parisian Diary (1930). Curiously, in this reply to a friend's (Adrienne Monnier) comment, we find a negative evaluation of photography as a means of reproduction. The philosopher complains that reproductions of works of art ruin all aesthetic pleasure ("L'Euvre d'Art", 117). Some of his friend's objections, particularly those stressing the fact that art must be viewed as a collective creation, seem to have influenced Benjamin to such an extent that in the "Small History of Photography" a new line of argument will be followed. A kind of materialistic conversion seems to take place. The term "aura" is now to be defined historically, in the same way as it appears in "The Work of Art":

We define the aura (...) as the unique phenomenon of distance, however close it may be. If, while resting on a summer afternoon, you follow with your eyes a mountain range on the horizon or a branch which casts its shadow over you, you experience the aura of those mountains, of that branch. ("Small History of Photography", 222)

Here, what we have is a spectator who contemplates objects feeling a sort of "pathos der Distanz". It does not matter if they are actually far from him or not, for the distance is ultimately in his way of perceiving. The important point is that one does not feel as being part of what one contemplates. According to Benjamin, it is the same situation of a certain aesthetics (in the broadest sense of the term, i.e., in relation to our perception). More precisely, it is the situation engendered during the Middle Ages and reinforced by all posterior idealistic tendencies. From this standpoint, l'art pour l'art ("art for art's sake") represents nothing else than a reaction to the changes that have been occurring since the Renaissance which tends to approach the spectator from the works of art.

What happens that profoundly changes the impact of art upon the spectator, capturing a new place for the artistic process? At first sight, the essential feature is merely negative. Even the most perfect reproduction lacks its own presence, since the original "thing" is not there, in time or in space. It is more a question about authenticity than genuineness for what really matters is the fact that the work of art is now emancipated from its character of object (as a fetish) ("The Work of Art", note 6, 244), and from a special context: "[F]or the first time in world history, mechanical reproduction emancipates the work of art from its parasitical dependence on ritual" ("The Work of Art", 224).

From now on, the original work does not bear any authority whatsoever. First: because the reproductions became independent of it. Second: because the copies can be now put into situations which would be out of reach for the original. They enable it to meet the beholder 
halfway: "The cathedral leaves its locale to be received in the studio of a lover of art: the choral production, performed in an auditorium or in the open air, resounds in the drawing room" ("The Work of Art", 221).

The objects of art are then reactivated. They do not refer to an original anymore, and they can be transported from one "space-time" to another. By means of reproduction they are detached from the domain of tradition. Benjamin opposes the former dependence on ritual to the increasing opportunities for exhibition in our (his) times. Here again, it is clear that his evaluation of the whole process of "liquidation of aura" is rather positive. "Cult value" is replaced by "exhibition value", in a sort of invitation for the public to participate, critically but also enjoying the works of art. Actually, distraction and concentration are not to be separated in an idealistic manner anymore. Benjamin gives the example of Georges Duhamel who complains that in film his thoughts are replaced by moving images, to which he replies: it is the "same ancient lament that the masses seek distraction whereas art demands concentration from the spectator" ("The Work of Art", 239).

This possibility of participation prepares new times for art. The negative theology of the so-called "pure" art consisted in denying any social function or any categorizing by subject-matter for art. Now that the criterion of authenticity ceases to be applicable to artistic production, the function (or pseudo-non-function) of art is reversed: "Instead of being based on ritual [or on pure form], it begins to be based on another practice - politics" ("The Work of Art", 224). Still concerning the idea of bringing the spectator into scene, Benjamin compares film and photography to painting and theater to show that they can be more powerful in demystifying art. Film, for instance, encourages the audience to assume a more critical attitude than theater does, because it allows the audience to identify with the actor through the camera ("The Work of Art", 228). Besides, film shows things "from different perspectives and enriches our field of perception" ("The Work of Art", 235).

Benjamin stresses, however, that all the beneficial consequences of the event (the "decay of the aura") do not come to fruition by themselves. They rest on two circumstances: the desire of contemporary masses to bring things "closer" spatially and humanly (1), and a change in their perception which has its "sense of universal equality" increased (2). Or, as he puts it: "the adjustment of reality to the masses and of the masses to reality" ("The Work of Art", 223). Without the concourse of these causes, ethical and aesthetic (again in the broad sense of a theory of sensibility), nothing will be (or can be) achieved - not even through film: "So long as the movie-makers' capital sets the fashion, as a rule no other revolutionary merit can be accredited to today's film than the promotion of a revolutionary criticism of traditional concepts of art" ("The Work of Art", 231).

Such a statement allows us to understand why, according to the philosopher, there is finally no common ground between the politicization of art and the fascist attempt to aestheticize politics. Perhaps the answer is that Fascism only gives us the illusion of suppressing the auratic distance found in tradition. Nonetheless, it is still the capital that sets the rules. The traditional concepts of art are criticized, but only insofar as they reveal themselves too weak to avoid the politicization of masses. Fascism needs something else, something mesmerizing. Its art (and the arts of reproduction are a weapon for Hitler and Mussolini too, like in Leni Riefenstahls's films) seeks to show the masses ("to give them a chance to express themselves" - "The Work of Art", 241), but without inviting them to think about their condition. The ritual values are still there, although they appear disguised. The spectator is brought into the scene, but as an object (aestheticization of politics). Conversely, a politicization of art claims for something different. It claims for a participation of the spectator who is now supposed to question his own conditions (as a subject). But this also presupposes an artist capable of setting the rules for art production. 
In this sense, we can say again (in response to Adorno) that Benjamin does not neglect the importance of the artist's autonomy. The question that remains though concerns the degree of autonomy he reserves to him. Should all new art form created indicate the way whereby property relations can be changed? Or is it enough to denaturalize them opening to new relations, even more complex than social relations? Is there a logic to follow or must artist and spectator invent their own logic of perception?

Benjamin's great admiration for Brecht's epic theater, as well as his emphasis on the notion of commitment and didactic art, finally suggest that the first alternative is the true one. But wouldn't the second version of politicization be more efficient in blocking the fallacies of l'art pour l'art and the Futurist-Fascist glorification of war and death?

\section{Politicization of Art and Will to Art}

Benjamin's views on cinema as an art of the masses are much indebted to a Marxist conception of politics. But it is this perspective that ultimately ruins part of his approach because the opposition between "politicization of art" and "aestheticization of politics" seems thus reduced to the general projects of Communism and Fascism ("The Work of Art", 242). By the same token, this rigid opposition tends to presuppose the agents of the polis (the masses or the people) in such a manner that the difference between "giving them their right" (the right to change property relations) and "giving them a chance to express themselves" (while preserving property) ("The Work of Art", 241) appears as quite abstract. In this respect (but only in this respect), it seems that Adorno is close to some truth when he affirms in his Aesthetic Theory:

The failure of Benjamin's grandly conceived theory of reproduction remains that its bipolar categories make it impossible to distinguish between a conception of art that is free of ideology to its core and the misuse of aesthetic rationality for mass exploitation and mass domination, a possibility he hardly touches upon (ADORNO, 56).

The problem of Adorno's assertion is that the distinction to be established is not between a conception "free of ideology" (whatever it may mean) and "the misuse of aesthetic rationality for mass exploitation and mass domination" but rather between a political conception of art that presupposes the people to whom the artist address himself and another one in which all social and political relations are still and always to be invented. Actually, there are no political conceptions free of ideology although there have been many attempts to exploit and dominate the masses through art - Riefenstahl's film Triumph of the Will produced in 1934 remains perhaps the best example of a very successful aesthetic enterprise of the kind. By the way, it is only this latter use of ideology that threatens and betrays art because what seems to characterize art is precisely a "will" that never fully identifies itself with a "truth" or a "cause".

In fact, the reason why Benjamin is unable to surmount the opposition between the Communist politicization of art and the Fascist aestheticization of politics is not related to an insufficient dialecticization of the problem, as Adorno postulated in his famous letter. Benjamin's so-called "bipolar categories" (ritual / political, cult value / exhibition value) do not imply any dismissal of the artist's creativity in the name of politics, nor do they praise the arts of reproduction (photography and film) in themselves. 
As two of the last footnotes of The Work of Art in the Age of Mechanical Reproduction indicate $^{3}$, Benjamin does not fail to note that the medium is not enough to assure a politicization of art. Nor does he forget, as we have already seen, that many artists continue to find refuge in the doctrine of l'art pour l'art in order to neutralize the power of art over people. He does not even ignore, in spite of certain optimism, the fact that the audience (the masses) itself is very often seduced by new auras. After all, "cult value does not give way without resistance" ("The Work of Art", 225).

The real "mistake" seems to lie elsewhere. It has probably to do with something more fundamental; namely, with Benjamin's basic concept of art. Even though modernity shows that "art" is nothing but a nominal concept, changing throughout the times; one can still argue that there must be a species of will to art (something like the famous critic Alois Riegl's Kunstwollen) beyond that. It is such a "will" that repeats itself by acquiring new forms in different periods of history. It is such a "will" that Adorno claims to be absent of Benjamin's essay when he writes in his obscure Paraliponema that "what is called aura is known to artistic experience as the atmosphere of the artwork, that whereby the nexus of the artwork's elements points beyond this nexus and allows each individual element to point beyond itself" (ADORNO, 274).

In other words, there is an aura of the work of art that is not based on ritual. Even if it is true that Benjamin never said the contrary and that Adorno distorted his friend's words, the question about the nature of this new, immanent, aura remains. Does Benjamin really leave room for such a possibility? If so, what would this other aura be exactly? What would be the "will to art" that succeeds in creating it? How would it be related to politics? Why would film be more capable of creating such an aura?

An attentive reading of another of Benjamin's essays ("On Some Motifs in Baudelaire") can help to answer a few of these questions. First of all, it is interesting to note that the text was written soon after "The Work of Art in the Age of Mechanical Reproduction". It is unlikely that the philosopher has changed his mind during such a short interval of time. However, he uses the term to designate a different experience. He talks about "the associations which, at home in the mémoire involontaire, tend to cluster around the object of a perception" ("On Some Motifs", 186). But an aura made out of free associations (Freud and Proust are the main references in this essay) no longer depends on any ritual.

What now best characterizes the phenomenon (aura) is a sort of response that the work of art is capable of giving back to the spectator. Benjamin's point of departure is an aesthetical definition given by Paul Valéry, according to which a work of art is recognized "by the fact that no idea it inspires in us, no mode of behavior that it suggests we adopt could exhaust it or dispose of it" ("On Some Motifs", 187). So, there is something inexhaustible in the work of art. What it gives to us is more than a mere likeness (a representation). A work of art before the age of mechanical reproduction evoked a mere compound of sense impressions. This tends to disappear with photography: "What was inevitably felt to be inhuman, one might even say deadly, in daguerreotypy, was the (prolonged) looking into the camera, since the camera records our likeness without returning our gaze" ("On Some Motifs", 187-188). This glance that does not look back is what the arts in the age of mechanical reproduction give to us.

\footnotetext{
3 "One technical feature is significant here, especially with regard to newsreels, the propagandist importance of which can hardly be overestimated. Mass reproduction is aided especially by the reproduction of the masses. In big parades and monster rallies, in sport events, and in war, all of which nowadays are captured by camera and sound recording, the masses are brought face to face to themselves" (Benjamin, 251). This note refers mainly to Fascism. In another note, Benjamin mentions the threat to life which modern man has to deal with in film. The idea is that the medium also offers all kinds of danger.
} 
That is probably the reason why Baudelaire saw the new media as "unnerving and terrifying", "startling and cruel" (On Some Motifs", 186). Yet, the poet himself was fascinated by this "decline of the aura". His poetry (his motifs) must actually be viewed as a celebration of the ephemeral element of the arts of reproduction. Baudelaire, the Modern artist par excellence. According to Benjamin, Baudelaire's insight into the phenomenon of the aura goes along with its disintegration in his own poetry. Nevertheless, he does not consent this disintegration without reinstating a kind of aura himself, through his idea of a shock as the new criterion for aesthetic experience.

In his book Mass Mediauras: Form, Technics, Media, the commentator Samuel Weber summarizes the arguments presented above:

What Baudelaire encounters (...) is the human equivalent of the apparatus: eyes that 'look up' but do not 'look back', or even look at. And with this glance that does not look back and yet sees, a very different kind of aura emerges: that of a singularity that is no longer unique, no longer the other of reproduction and repetition but their most intimate effect. What Benjamin calls the 'decline of aura' emerges here not as its simple elimination but as its alteration (WEBER, 104).

From this perspective, the essay on Baudelaire shows that Benjamin does admit the possibility of a different type of aura. The aura of the age of mechanical reproduction would be this shock, effect or impact that words, sounds or images wield upon us, which disrupts our perception by not offering any response or feedback. Instead, the spectator becomes critical about the representation. This is not only the cases of Baudelaire's poetry and the arts of reproduction (Eugène Atget's photographs and cinema in general), but most fundamentally what occurs in Brecht's epic theater.

Benjamin's essay on the German playwright finally provides a key to understand what could be his general approach of aesthetics, his basic concept of art or his idea about the will to art that lies under the creation of different auras throughout history. Brecht's attempt to create a non-Aristotelian drama clearly belongs to our times insofar as it puts accent on the interruption of events. It is the so-called Verfremdungseffekt (effect of estrangement) whereby the spectator is able to discover the conditions of life instead of identifying with the development of the events. This new epic theater "consists in producing astonishment rather than empathy" ("What is Epic Theater?", 150), but Benjamin also notes that the Brechtian path is, to a certain extent, a recuperation of the legacy of the medieval and Baroque drama.

One finds here a decisive connection with a capital text written by Benjamin ten years before the essay on mechanical reproduction, titled The Origin of German Baroque Drama, in which he develops what can be viewed as his key-concept of aesthetics - the concept of "allegory". It is probably this very concept that subsumes all sorts of aura. Astonishment and estrangement are ways of displacing, dislocating. In short, Benjaminian will to art is basically allegorical.

The problem is to understand how this will to art - related to ritual in the past - now relate to the political realm. In order to answer this question, it would be necessary to look closely into cinema. After all, according to Benjamin himself, film is the most powerful agent of the liquidation (one must say from now on: transformation) of the aura.

Film would be the best medium to induce a shift in property relations. But film may be even more capable than that. Instead of presupposing the people and its social relations, it may be the case that what is really strong in film lies in its capacity to denaturalize these relations, opening to new ones, even more complex than the social ones. In short, there would be two forms of relating an allegorical will to art to the realm of politics - two forms of politicization of art: the one that is explicitly admitted and sustained by Benjamin (which can 
be found in Brecht's epic and didactic theater) and another one, still to be decrypted (maybe in Benjamin himself), where either the people and the social relations remain open and must be constantly reinvented...

\section{WORKS CITED AND CONSULTED:}

- Adorno, Theodor. Aesthetic Theory. Edited by Gretel Adorno and Rolf Tiedemann. Translated and edited with an Introduction by Robert Robert Hullot-Kentor. Minneapolis: U.P. of Minnesota, 1997.

- Benjamin, Walter. "The Author as Producer", in Twentieth-Century Literary Theory. Edited and introduced by Newton, K.M. New York: St. Martin's Press, 1988.

. "What is Epic Theater?”, “On Some Motifs in Baudelaire”, and “The

Work of Art in the Age of Mechanical Reproduction", in Illuminations. Edited with an

Introduction by Hannah Arendt. Translated by Harry Zohn. New York: Schocken

Books, 1977.

"L’Oeuvre d'Art à l'Époque de sa Reproduction Mécanisée", in Écrits

Français. Présentés et introduits par Jean-Maurice Monnoyer. Avec les témoignages d'Adrienne Monnier, de Gisèle Freund et de Jean Selz. Paris: Gallimard, 1991.

- Rochlitz, Rainer. The Disenchantment of Art: The Philosophy of Walter Benjamin. Translated by Jane Marie Todd. New York: Guilford Press, 1996.

- Taylor, Ronald (Translation Editor). Aesthetics and Politics. Manchester: NLB, 1979.

- Weber, Samuel. Mass Mediauras: Form, Technics, Media. Edited by Alan Cholodenko. Stanford UP, 1996. 